Левчук О. В., к.екон.н., доцент (ORCID 0000-0002-2827-2134)

Центр воєнно-стратегічних досліджень Національного університету оборони України імені Івана Черняховського, Київ

\title{
Тенденції формування нових торговельно-економічних альянсів держав
}

Резюме. Розглянуто ключові аспекти функціонування національної економіки України в умовах міжнародної інтеграції. Надано загальну характеристику та деякі особливості процесу здійснення оборонних закупівель. Досліджено роль процесу міжнародної економічної інтеграції в забезпеченні колективної безпеки. Проаналізовано структуру закупівель імпортної продукції. Визначено основні підходи до формування і розвитку нових торговельно-економічних альянсів під впливом зовнішніх факторів.

Ключові слова: міжнародна економічна діяльність; зовнішня торгівля; внутрішній ринок; конкурентоспроможність; імпортозалежність ринку.

Постановка проблеми. Характерною ознакою сучасного світу $є$ посилення взаємозалежності економік різних країн, розвиток інтеграційних процесів в окремих регіонах на мікро- та макрорівнях. Відбувся інтенсивний перехід цивілізованих країн від закритих національних господарств до економіки відкритого типу, зверненої до навколишнього світу й ефективної міжнародної співпраці. Процес міжнародної співпраці зумовлено: всебічним розвитком i постійним поглибленням міжнародного поділу праці - від простого обміну товарами до стійкої міжнародної торгівлі товарами і послугами; міжнародною міграцією капіталів i формуванням нових виробництв; тісною виробничою $\mathrm{i}$ технічною кооперацією. Наслідком таких переміщень $є$ управління міжнародним бізнесом на міждержавному рівні. Поступово формуються регіональні економічні зв'язки, які можуть охоплювати десятки країн усередині регіону. Міжнародна економічна інтеграція (MEI) набуває практичного втілення у низці інтеграційних об'єднань світу, які визначають стан i перспективи подальшого розвитку міжнародних економічних зв'язків загалом, i міжнародного бізнесу зокрема. В основу формування торговельно-економічних зв'язків між різними країнами світу покладено принцип ефективності використання наявних або доцільності залучення певних ресурсів.

Аналіз останніх досліджень i публікацій. Вагомий внесок у теоретичне дослідження особливостей міжнародної економічної діяльності України зроблено такими науковцями, як Т. Мельник, А. Мазаракі, I. Багрова, Н. Кухарська,
М. Дідківський, В. Новіцький, А. Вічевич та інші [6]. Утім, варто зазначити, що достеменно досліджено такі основні форми економічної співпраці, як експортно-імпортні операції, ліцензування, квотування, патентування, преференційні торговельні угоди, спільний ринок тощо.

Актуальність обраної теми дослідження зумовлена необхідністю формування i розвитку ефективних шляхів воєннополітичної й економічної інтеграції України у світове співтовариство та захисту інтересів національних товаровиробників на міжнародному ринку.

Метою статті $\epsilon$ узагальнення основних підходів до процесу формування i розвитку нових торговельно-економічних альянсів України під впливом зовнішніх факторів.

Виклад основного матеріалу. $\mathrm{y}$ процесі активного перерозподілу світових та регіональних ринків збуту державі вкрай важливо забезпечити реалізацію специфічних переваг, пов'язаних із міжнародним співробітництвом, поділом праці та факторним розміщенням.

Теоретичним та методологічним підгрунтям вивчення проблематики $\epsilon$ синергетичний підхід до визначення економічних, соціальних і правових процесів, наукові праці, монографії, нормативно-правові акти та інші джерела.

Міжнародна економічна діяльність України $є$ одним з пріоритетних напрямів руху держави, що створює підгрунтя для подальшого розвитку торгівлі та сприятливого інвестиційного клімату. Зовнішня торгівля формує значні можливості для економічного зростання, формування бюджету країни, підтримання добробуту іiі громадян. 
Відсутність

розв'язання

внутрішнього

\section{стратегічного}

проблеми

підходу до

збільшення

ринку через

насичення

обсягів внутрішнього

виробництва призвела до формування

високого рівня залежності внутрішнього ринку від імпорту та до необхідності нарощування експорту для покриття дефіциту рахунку поточних операцій платіжного балансу.

Варто зазначити, що саме відкритість економіки є загрозою, власне, внутрішньому ринку країни. На практиці це призводить до коливань зовнішньої кон'юнктури ринків і акумуляції загальних світових тенденцій (волатильність цін на енергоносії, зменшення цін на основні товари українського експорту тощо). Відтак, виникає потреба у зниженні показника імпортозалежності товарного ринку, створенні сприятливих умов щодо зовнішніх ринків, забезпеченні позитивного впливу імпорту на виробництво, i, як наслідок, зміцнення конкурентоспроможності вітчизняної економіки.

Світова

практика переконливо демонструє, що пасивна роль держави в системі регулювання імпорту товарів поступово призводить до втрати окремими галузями економіки конкурентоспроможності навіть на внутрішньому ринку.

Роль держави у процесі імпортозаміщення полягає у наданні організаційного та адміністративного сприяння бізнесу 3 розвитку тих видів діяльності, які будуть комерційно вигідними. До того ж особливу увагу в цьому разі слід звертати на доцільність залучення європейських чи інших виробників аналогічної продукції. Позитивною тенденцією в цьому разі $є$ формування у ділових кіл інтересу до диверсифікації підприємницької діяльності, виробництва в Україні нових товарів або таких, що дійсно матимуть споживчий попит за інших рівних умов, створення ринкової інфраструктури, орієнтованої на експорт.

Прийняття Верховною Радою України Закону України “Про внесення змін до деяких законодавчих актів України щодо закупівлі продукції, робіт i послуг оборонного призначення за імпортом" забезпечить вирішення низки питань, що стосуються подальшого успішного розвитку вітчизняного військово-промислового комплексу на приведення його у відповідність до стандартів НАTO [1]. Інакше кажучи, Міністерству оборони, як кінцевому споживачу товарів військового призначення, надходила продукція, яка не завжди відповідала заявленій вартості та якісним характеристикам. Відповідно, із введенням в дію Закону України, з'являється можливість узяти безпосередньо під власний контроль доцільності придбання, якості та вартості продукції оборонного призначення.

Військово-технічне співробітництво діяльність у сфері двосторонніх відносин, пов'язана 3 розробленням, виробництвом, ремонтом, модернізацією, знищенням (утилізацією) та міжнародними передачами товарів (вивезенням і ввезенням, зокрема 3 поставкою чи закупівлею продукції - для сторони - партнера угоди) військового призначення [3].

Економічна інтеграція (economic integration - англ.) - процес економічної взаємодії країн, який призводить до зближення господарських механізмів і набирає форми міждержавних угод та узгоджено регулюється міждержавними органами [5].

Згідно 3 чинним законодавством, економічний регіоналізм (економічне співробітництво) - наслідок інтеграційних процесів, унаслідок яких окремі групи країн створюють між собою сприятливіші умови для торгівлі та (в окремих випадках) для руху факторів виробництва, ніж для всіх інших країн [4].

Зростатиме економічна доцільність забезпечення потреб ЗС України необхідними товарами або послугами із внесенням змін в абзац перший частини третьої статті 7 Закону України, а саме: "У разі, якщчо закупівля продукиії, робіт $i$ послуг за оборонним замовленням становить державну таємницюю, така продукиія, роботи $i$ послуги можуть також закуповуватись у іноземних суб'єктів господарювання за умови, що ідентична продукиія 3 аналогічними якісними показниками не виробляється, роботи не виконуються, а послуги не надаються в Україні" [1]. У кінцевому підсумку це дасть змогу збереження часу, матеріальних ресурсів i коштів. Відповідно, зусилля можна сконцентрувати на розробленні необхідної техніки (товарів, робіт, послуг) всередині країни, а закупівлі здійснювати з урахуванням впливу факторів часу, ризику та ліквідності.

Зміни у статті 8 Закону України конкретизують кінцевого споживача продукції оборонного призначення, оскільки визначають його як “офсетного бенефіціара", що 
унеможливить вплив посередників на процес закупівель.

Для вирішення питань організації та координації діяльності стосовно проведення переговорів $з$ іноземною юридичною особою щодо одержання Україною компенсацій, укладення та виконання компенсаційних (офсетних) договорів запропоновано Кабінету Міністрів України утворити постійно діючу офсетну комісію у складі представників державних замовників, інших державних органів, підприємств, установ та організацій. Отже, порядок укладення зазначених договорів визначатиметься виключно Кабінетом Міністрів України.

Варто звернути увагу на частину четверту Закону України. Так, закупівля продукції, робіт, послуг оборонного призначення за імпортом для забезпечення потреб державного замовника може здійснюватись в іноземних юридичних осіб через [1]: укладення державним замовником (або уповноваженим ним суб'єктом господарювання) держсавного контракту 3 іноземною юридичною особою - виробником або постачальником продукції, робіт, послуг оборонного призначення, у разі надання в установленому законодавством порядку такому державному замовнику повноважень на право здійснення імпорту товарів військового призначення і товарів, які містять відомості, що становлять державну таємницю; укладення державним замовником держсавного контракту 3 вітчизняним суб'єктом господарювання, якому в установленому законодавством порядку надані повноваження на право здійснення експорту та імпорту товарів військового призначення i товарів, які містять відомості, що становлять державну таємницю.

Інформація щодо закупівель імпортної оборонної продукції наведена у табл. 1.

Таблиця 1

Структура закупівель імпортної оборонної продукції"

\begin{tabular}{|c|c|c|c|c|}
\hline $\begin{array}{l}\text { № } \\
\text { II/II }\end{array}$ & Вид озбросння / військової техніки & $\begin{array}{c}\text { Країна-виробник / } \\
\text { постачальник }^{*}\end{array}$ & $\begin{array}{c}\text { Характер } \\
\text { відносин }\end{array}$ & Примітка \\
\hline 1 & БТР (двигуни) & Німеччина & Разові угоди & \\
\hline 2 & Танки & Німеччина, Пакистан, Таїланд & Разові угоди & \\
\hline 3 & Військові літаки (Airbus, Boeing) & США & Разові угоди & \\
\hline 4 & Гелікоптери & Франція & Разові угоди & \\
\hline 5 & Корабельний склад: & США, Британія & Разові угоди & \\
\hline 5.1 & Патрульні катери типу "Island" & США & Разові угоди & \\
\hline 6 & Ракети (ПТРК “Javelin Fgm- 148”) & США & Разові угоди & $\begin{array}{lr}\text { Загальна } & \text { вартість } \\
\text { контракту } & \text { понад } \\
47 \text { млн дол. } & \\
\end{array}$ \\
\hline 7 & Медичне обладнання, медикаменти & $\begin{array}{c}\text { Японія, Канада, Ізраїль, Литва, } \\
\text { Німеччина }\end{array}$ & Разові угоди & \\
\hline 8 & Паливно-мастильні матеріали & Азербайджан, Катар, Білорусь & Разові угоди & \\
\hline 9 & Засоби спеціального зв'язку ASELSAN & Туреччина & $\begin{array}{c}\text { Можливість } \\
\text { реалізації } \\
\text { офсетної } \\
\text { програми } \\
\end{array}$ & $\begin{array}{l}\text { Готовність турецької } \\
\text { сторони до передачі } \\
\text { технології виробництва }\end{array}$ \\
\hline
\end{tabular}

"Джерело: узагальнено автором за даними мережі Інтернет

За даними табл. 1 можна дійти висновку, що під час формування нових напрямів військово-економічного співробітництва слід брати до уваги досвід роботи країн світу, співпраця 3 якими $\epsilon$ перспективнішою. Відповідно, перевага в такому разі надається розумному співвідношенню між ціною та якістю конкуруючих товарів або аналогічних вітчизняних розробок, а також врахування потреб Збройних Сил у доцільності вибору певного напряму співробітництва.

3 огляду доцільності формування нових військово-економічних альянсів для нашої країни загалом, і для Збройних Сил України зокрема, слід звернути увагу на необхідність постійного підвищення рівня професійної підготовки особового складу. Для цього варто враховувати специфіку та досвід проведення міжнародних навчань. Інформація щодо міжнародної співпраці 3С України 3 країнами-партнерами наведена у табл. 2 [2].

Варто зазначити, що практично усі поняття, які застосовуються на сьогодні наукою для виокремлення ролі й місця людини у суспільстві, не виходять за межі підходу до людини як до об'єкта капіталовкладень. Виробництво ж (матеріальне і духовне), здебільшого й досі звелено до самоцілі, хоча й історично, і логічно воно - інструмент забезпечення розвитку людини. Людина визнається важливою, перспективною, ефективною, але інструментальною цінністю.

Теорія людського капіталу надає логічне пояснення структурі розподілу особистих доходів, віковій динаміці 
заробітків, гендерній дискримінації на ринку праці. Саме ця теорія стала поштовхом до значних інвестицій в освіту та професійну підготовку на всіх рівнях, оскільки вони розглядаються як ефективне джерело формування i нарощення людського капіталу, i, відповідно, економічного зростання будь-якої країни. Питання ролі та місця продуктивних здібностей людини, їх ефективного формування i використання завжди викликали підвищений інтерес вчених, тому виникнення концепції розвитку людського капіталу стало закономірним результатом світової економічної та філософської думки [7].

Міжнародне співробітництво окремих видів ЗС України*

Таблиця 2

\begin{tabular}{|c|c|c|c|}
\hline $\begin{array}{l}\text { № } \\
\text { II/II }\end{array}$ & $\begin{array}{c}\text { Види Збройних } \\
\text { Сил України }\end{array}$ & $\begin{array}{c}\text { Країни-партнери по } \\
\text { співробітництву }\end{array}$ & $\begin{array}{c}\text { Види військових навчань, назва, } \\
\text { рік проведення }\end{array}$ \\
\hline \multirow{7}{*}{1} & \multirow{7}{*}{$\begin{array}{l}\text { Сухопутні війська } 3 \mathrm{C} \\
\text { України }\end{array}$} & США & КШН “Репід-Трейдент”, 2016 \\
\hline & & Естонська республіка & БНН “Спрінг-Сторм”, 2016 \\
\hline & & Литва & БПТН “Хантер-2016” \\
\hline & & Німеччина & БНБР “Комбайн-Резолв”, 2016 \\
\hline & & Греція & КШН “МІЛЕКС-16”, 2016 \\
\hline & & Литва & БТН “Айрон-Вульф”, 2016 \\
\hline & & Румунія & БКШН “Сейбер Гардіан-2016” \\
\hline \multirow{4}{*}{2} & \multirow{4}{*}{$\begin{array}{l}\text { Військово-Морські } \\
\text { Сили ЗС України }\end{array}$} & Країни-члени НАТО та ЄС & Чергування у складі БТГ “Хелброк” \\
\hline & & Туреччина & $\begin{array}{l}\text { Систематичне проведення в північно-західній } \\
\text { частині Чорного моря навчань типу } \\
\text { "ПАСЕКС" }\end{array}$ \\
\hline & & $\begin{array}{l}\text { США } \\
\text { Також періодично беруть участь: } \\
\text { Болгарія, Велика Британія, Греція, } \\
\text { Грузія, Італія, І Іпанія, Литва, } \\
\text { Молдова, Норвегія, Польща, Румунія, } \\
\text { Туреччина, Швеція і Фінляндія }\end{array}$ & $\begin{array}{l}\text { Координація проведення на території України } \\
\text { міжнародних навчань “Сі Бриз” }\end{array}$ \\
\hline & & Країни-члени НАТО, Туреччина & $\begin{array}{l}\text { Участь в антитерористичних операціях НАТО } \\
\text { “Активні зусилля" та ВМС Турецької } \\
\text { Республіки "Чорноморська гармонія" }\end{array}$ \\
\hline \multirow[t]{2}{*}{3} & \multirow{2}{*}{$\begin{array}{l}\text { Повітряні Сили 3C } \\
\text { України }\end{array}$} & США & МН “Сi Бриз-2016” \\
\hline & & Країни-члени НАТО & КШН НАТО “Трайдент Джанкчер-2016” \\
\hline 4 & $\begin{array}{l}\text { Десантно-штурмові } \\
\text { війська ЗС України }\end{array}$ & \multicolumn{2}{|c|}{ Інформачія відсутня } \\
\hline 5 & 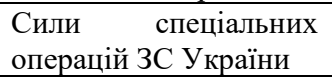 & \multicolumn{2}{|c|}{ Інформація відсутня } \\
\hline
\end{tabular}
напрями військово-економічного співробітництва у сфері формування i нарощування специфічного людського капіталу, підвищення рівня освіти та професійної підготовки особового складу слід розбудовувати спільно із США, країнамичленами НАТО, СС, Туреччиною, Грузією та iH.

За інформацією Стокгольмського міжнародного інституту досліджень миру, можна дійти висновку, що глобальний ринок зброї хоч і не надто змінився за розмірами, але зазнав помітних змін за своєю структурою [8]. Зокрема, обсяги торгівлі основними видами озброєнь на планеті в 2014 - 2018 рр. зросли на 7,8 \% порівняно з періодом 2009 - 2013 рр. За своїми темпами вони не надто відрізняються від загальносвітових тенденцій розвитку світової економіки. У середньому, на купівлю зброї витрачають ту саму “непропорційно велику частку валового світового продукту”, що й раніше [8].
Висновки. Зважаючи на викладене, варто зазначити, що головним трендом у формуванні нових торговельно-економічних (у даному випадку - воєнно-економічних) альянсів держав є раціональність, доцільність i взаємна економічна вигода від міжнародної співпраці з партнерами.

\section{СПИСОК ВИКОРИСТАНОЇ ЛІТЕРАТУРИ}

1. Про внесення змін до деяких законодавчих актів України щодо здійснення закупівлі продукції, робіт i послуг оборонного призначення за імпортом: Закон України № 2672 - VIII від 17.01.2019 р. - [Електронний ресурс]. - URL: https://zakon.rada.gov.ua/laws/show/267219?lang=uk

2. Офіційний сайт Міністерства оборони України. - URL: http://www.mil.gov.ua/ministry/skladzbrojnix-sil-ukraini

3. Угода між Кабінетом Міністрів України та Урядом Республіки Білорусь про взаємну охорону прав на результати інтелектуальної діяльності, що створені та надані в ході двостороннього військово-технічного 
співробітництва / Законодавство України. - URL: https://zakon.rada.gov.ua/laws/term/4167:715

4. Положення про Міністерство закордонних справ України / Мін-во закордонних справ України. URL: https://zakon5.rada.gov.ua/laws/show/2812016-\%D0\%BF

5. Козик В. В., Панкова Л. А., Григор'єв О. Ю., Босак А. О. Міжнародна економіка та міжнародні економічні відносини: Практикум. - 2-ге вид., перероб. і доп. - К.: Вікар, 2006. - 589 с. C. $289-290$.

6. Мельник Т. М., Таран I. В. Міжнародна економічна діяльність України: Навчально- методичне видання // Т. М. Мельник, I. В. Таран. - К.: ЦПНМВ КНТЕУ, 2014.

7. Левчук О. В. Управління інвестиціями у людський капітал [Рукопис] : автореф. дис. ... канд. економ. наук: 08.00.03 - економіка та управління національним господарством / О. В. Левчук ; Національний аграрний університет. - К., 2008 . 20 с. -УДК 658.012:331.107.266.2. http://irb.nubip.edu.ua

8. SIPRI Yearbook 2018 / Stockholm International Peace Research Institute. URL: https://www.sipri.org/sites/default/files/SIPRIYB18c 01.pdf

Стаття надійшла до редакційної колегії 24.10.2018

\section{Левчук Е. В., к.экон.н., доцент}

Центр военно-стратегических исследований Национального университета обороны Украин имени Ивана Черняховского, Киев

Тенденции формирования новых торгово-экономических альянсов государств

Резюме. Рассмотрены ключевые аспекты функционирования национальной экономики Украины в условиях международной интеграции. Предоставлена общуя характеристика и некоторые особенности процесса осуществления оборонных закупок. Исследована роль процесса международной экономической интеграции в обеспечении коллективной безопасности. Проанализирована структура закупок импортной продукции. Определены основные подходы к формированию и развитию новых торгово-экономических альянсов под влиянием внешних факторов.

Ключевые слова: международная экономическая деятельность; внешняя торговля; внутренний рынок; конкурентоспособность; импортозависимость рынка.

\section{E. Levchuk, PhD (Economic), assistant professor}

Center for Military and Strategic Studies of the National Defence University of Ukraine named after Ivan Cherniakhovskyi, Kyiv

\section{Trends in the formation of new trade and economic alliances of states}

Resume. The key aspects of the functioning of the national economy of Ukraine in the context of international integration are considered. A general description and some features of the defense procurement process are provided. The role of the process of international economic integration in ensuring collective security is investigated. Analyzed the structure of the procurement of imported products. The main approaches to the formation and development of new trade and economic alliances under the influence of external factors are defined.

Keywords: international economic activity; foreign trade; domestic market; competitiveness; import dependence of the market. 